\title{
Paul Zumthor, Essai de poétique médiévale
}

\section{G. Matteo Roccati}

\section{(2) OpenEdition}

\section{Journals}

\section{Édition électronique}

URL : http://journals.openedition.org/studifrancesi/35637

DOI : 10.4000/studifrancesi.35637

ISSN : 2427-5856

\section{Éditeur}

Rosenberg \& Sellier

\section{Édition imprimée}

Date de publication : 1 juillet 2005

Pagination : 126

ISSN : 0039-2944

\section{Référence électronique}

G. Matteo Roccati, «Paul Zumthor, Essai de poétique médiévale », Studi Francesi [En ligne], 145 (XLIX I

I) | 2005, mis en ligne le 30 novembre 2015, consulté le 19 avril 2021. URL : http://

journals.openedition.org/studifrancesi/35637 ; DOI : https://doi.org/10.4000/studifrancesi.35637

\section{Ce document a été généré automatiquement le 19 avril 2021.}

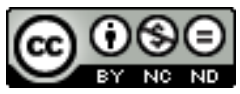

Studi Francesi è distribuita con Licenza Creative Commons Attribuzione - Non commerciale - Non opere derivate 4.0 Internazionale. 


\title{
Paul Zumthor, Essai de poétique médiévale
}

\author{
G. Matteo Roccati
}

\section{RÉFÉRENCE}

PAUL ZUMTHOR, Essai de poétique médiévale, avec une préface de Michel zinK et un texte inédit de Paul zUмTHOR, Paris, Éditions du Seuil («Points/Essais», 433), 2000; pp. 622.

1 Réimpression en format de poche de l'édition de 1972, enrichie d'une préface par Michel Zink et, en postface, des quelques pages que Paul Zumthor avait rédigées en 1985 pour les quinze ans de l'Essai et dont la traduction figure en tête de l'édition anglaise (Toward a Medieval Poetics, 1991). Les deux textes sont intéressants pour comprendre la démarche scientifique de l'A. Travaillant à une «science des textes» dont l'exigence et l'ambition étaient de dépasser l'histoire littéraire et participant entièrement du structuralisme de l'époque, il l'adapte à une perspective qui ne néglige nullement la compréhension historique ni le travail philologique et qui s'inscrit dans un itinéraire intellectuel intégrant les sollicitations les plus valables (Hjelmslev, Greimas, Jauss, etc.). 